\title{
Karakteristik Osilometrik dari Simulator Tekanan Darah
}

\author{
FUAD UGHI, GREGORIUS ALVIN DEWANTO
}

\author{
Biomedical Engineering, Swiss German University \\ Email: fuad.ughi@sgu.ac.id
}

\begin{abstract}
ABSTRAK
Dalam proses evaluasi performa tensimeter otomatis, simulator tekanan darah biasa digunakan sebagai nilai referensi. Simulator akan memberikan osilasi tekanan yang merepresentasikan detak jantung pada manset tensimeter untuk menyimulasikan tekanan darah sesuai metode osilometrik. Studi ini merupakan bagian dari pengembangan simulator tekanan darah. Studi ini bertujuan untuk menganalisis karakteristik osilometrik dari sebuah simulator tekanan darah komersial, untuk kemudian digunakan sebagai data referensi untuk pengembangan simulator tekanan darah. Data osilometrik diambil dari simulator komersial dengan menggunakan sistem akuisisi data berbasis LabVIEW. Pengambilan data untuk beberapa simulasi tekanan darah orang dewasa yang tersedia pada simulator dilakukan dengan metode pengukuran deflasi. Data diperoleh dengan metode pengukuran deflasi. Titik mulai osilasi adalah $20 \mathrm{mmHg}$ di atas nilai sistol dan terjadi perbedaan tingkat penurunan osilasi setelah 5 $\mathrm{mmHg}$ di bawa nilai diastol. Untuk detak jantung 80 detak per menit, osilasi terjadi setiap 750 milidetik. Nilai mean arterial pressure berbeda untuk tiap nilai tekanan darah.
\end{abstract}

Kata kunci: karakteristik, osilometrik, simulator, tekanan darah, tensimeter.

\begin{abstract}
In a performance evaluation process of an automatic sphygmonamometer a blood pressure simulator is usually used as reference input. A blood pressure simulator will generates pressure oscillation which represents heart beat to simulates blood pressure as in oscillometric method. This study is part of development of low-cost blood pressure simulator. This study analyze oscillometric characteristic of a blood pressure simulator that the result is used as reference for the development of blood pressure simulator. Oscillometric data was acquired from a commercial simulator using data acquisition system that based on LabVIEW. Data was taken for a few preset blood pressure simulations with deflation measurement method. Data was gathered with deflation measurement method. Starting point of oscillation is at $20 \mathrm{mmHg}$ above the sistolic value and there is different decreasing slope after $5 \mathrm{mmHg}$ below the diastolic value. For pulse 80 beat per minute, the oscillation occurs every 750 milisecond. The mean arterial pressure is different for each blood pressure value.
\end{abstract}

Keywords: characteristic, oscillometric, simulator, blood pressure, sphygmomanometer. 


\section{PENDAhUlUAN}

Terdapat dua metode yang sering digunakan dalam pengukuran tekanan darah. Metode pertama adalah metode auskultasi atau metode manual, menggunakan sebuah tensimeter dan stetoskop, dan memerlukan seorang operator yang telah terlatih untuk mendengar denyut pada pembuluh darah yang merepresentasikan nilai sistol dan diastol. Gambar 1 menunjukkan pengukuran tekanan darah dengan metode auskultasi.

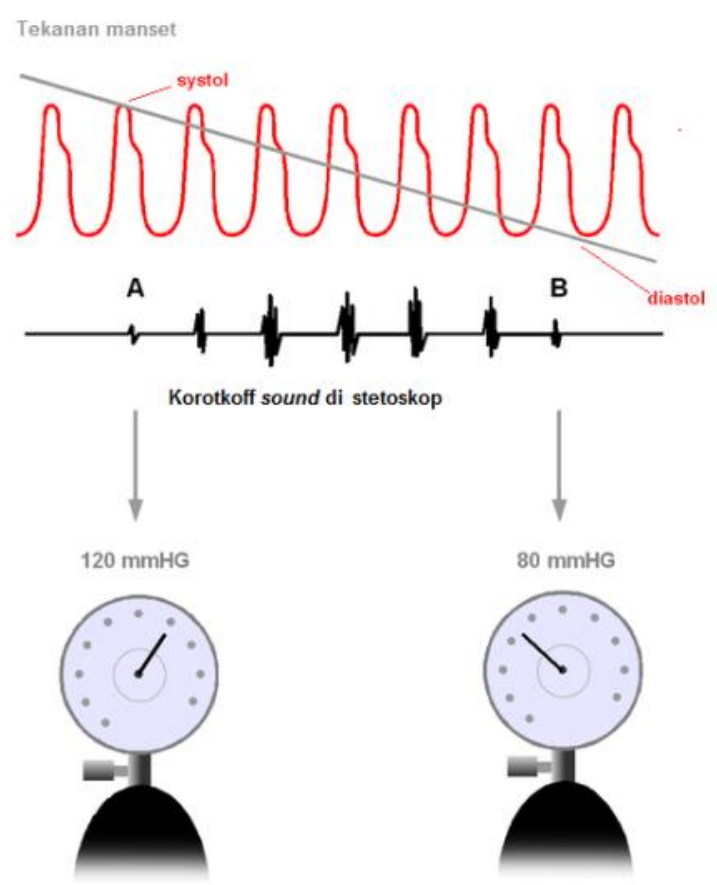

Gambar 1. Metode auskultasi (Sumber : https://commons.wikimedia.org)

Metode kedua adalah metode osilometrik, metode yang paling populer digunakan oleh tensimeter otomatis (Ball-llovera, dkk, 2003). Pada metode osilometrik, osilasi tekanan pada manset tensimeter yang disebabkan oleh denyut pada pembuluh darah digunakan untuk menentukan nilai sistol dan diastol. Tiap produsen memiliki algoritmanya sendiri untuk menentukan nilai sistol dan diastol dari data osilometrik (Ball-Ilovera, dkk., 2003). Gambar 2 menunjukkan data tipikal pengukuran tekanan darah noninvasif dengan metode osilometrik.

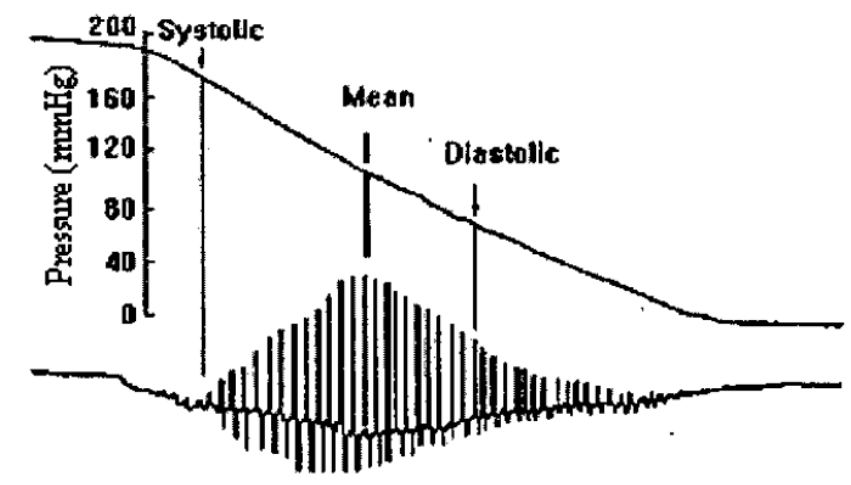

Gambar 2. Metode osilometrik (Ball-llovera, dkk, 2003) 
Untuk proses evaluasi tensimeter otomatis, biasanya digunakan simulator tekanan darah noninvasif sebagai nilai referensi atau nilai standar (Geršak, dkk, 2009). Biasanya terdapat beberapa preset tekanan darah untuk disimulasikan dengan beberapa mode pilihan, seperti mode standar, neonatal, arrhythmia, dan pengukuran di pergelangan tangan (Fluke, 2007). Pada dasarnya simulator tekanan darah ini menggantikan pasien sebagai input pada tensimeter otomatis. Prinsip kerjanya adalah sebagai berikut. Manset tensimeter otomatis dipasangkan pada sebuah tabung sembarang yang cukup keras dan kira-kira sebesar lengan, dan selang udaranya dicabangkan menjadi dua cabang untuk dihubungkan ke tensimeter otomatis dan simulator tekanan darah. Seiring dengan tensimeter diaktifkan dan pompa dari tensimeter memberi tekanan udara pada manset, simulator akan mendeteksi besaran tekanan udara di manset dan memberikan tambahan osilasi tekanan yang merepresentasikan denyut pada pembuluh darah pada rentang tekanan tertentu sesuai dengan nilai tekanan darah yang disimulasikan.

Evaluasi tensimeter ,baik itu analog ataupun digital, cukup penting. Kesalahan pembacaan dapat mengakibatkan kesalahan tindakan medis. Jika seseorang dengan tekanan darah tinggi dan melakukan pengukuran mandiri dengan tensimeter digital yang tidak akurat, bisa jadi hasil pembacaan lebih sering menunjukkan tekanan darah normal (Plante, dkk, 2016). Pengabaian penyakit tekanan darah tinggi dapat menyebabkan komplikasi yang membahayakan yang dapat berujung pada kematian atau kecacatan (Perhimpunan Hipertensi Indonesia, 2012).

Studi ini merupakan bagian dari pengembangan low-cost simulator tekanan darah. Untuk menyederhanakan proses pengembangan maka karakteristik osilometrik dari simulator yang akan dikembangkan akan mengacu pada karakteristik dari simulator komersial yang ada di Balai Pengamanan Fasilitas Kesehatan Jakarta. Untuk itu, studi ini bertujuan untuk menganalisis karakteristik osilometrik dari simulator tekanan darah noninvasif komersial, sehingga kemudian hasilnya dapat berguna sebagai referensi bagi pengembangan simulator tekanan darah atau bahkan pengembangan tensimeter otomatis.

\section{METODOLOGI}

\subsection{Pengambilan Data}

Pengambilan data dilakukan di Laboratorium Pengujian dan Kalibrasi Instrumen Medis, Balai Pengamanan Fasilitas Kesehatan (BPFK) Jakarta pada bulan Januari 2016. Simulator yang digunakan sebagai referensi adalah tipe BP Pump 2 Non Invasive Blood Pressure Monitor Analyzer dari Fluke Biomedical.

Fokus pada studi ini adalah pada variasi tekanan darah pada mode Standard BP yang tersedia pada instrumen. Variasi tekanan sistol/diastol pada mode Standard BP adalah sebagai berikut: (1) $120 / 80 \mathrm{mmHg}$; (2) $150 / 100 \mathrm{mmHg}$; (3) $200 / 150 \mathrm{mmHg}$ ); (4) $60 / 30$ mmHg; (5) $80 / 50 \mathrm{mmHg}$; (6) $100 / 65 \mathrm{mmHg}$. Seluruh variasi tekanan darah tersebut disimulasikan dengan detak jantung 80 beat per minute (BPM). Setiap variasi akan diambil sebanyak tiga kali agar ada data pembanding.

Proses pengambilan data dilakukan dengan menggunakan sistem akuisisi data berbasis LabVIEW yang dikembangkan sendiri. Metode pengukuran yang digunakan adalah metode deflasi, yaitu dengan memberi tekanan udara pada manset di atas nilai sistol lalu mengurangi tekanannya secara perlahan sembari melakukan pengambilan data osilometrik yang dihasilkan. Tekanan udara pada manset dipompa secara manual menggunakan pompa karet yang biasa digunakan pada tensimeter manual dengan katup deflasi dalam kondisi 
tetap, sehingga diharapkan kecepatan penurunan tekanan udara relatif sama pada setiap pengambilan data.

\subsection{Sistem Akuisisi Data}

Seperti telah disebutkan sebelumnya bahwa proses pengambilan data menggunakan sistem akuisisi data menggunakan sistem berbasis LabVIEW yang dikembangkan sendiri. Software berbasis LabVIEW digunakan untuk membaca dan merekam output sensor tekanan dan output band pass filter (BPF) yang berupa osilasi yang dihasilkan oleh simulator. Pada dasarnya sistem akuisisi data ini mirip dengan sistem penyusun tensimeter otomatis tanpa pompa otomatis dan tanpa algoritma penentuan nilai sistol dan diastol. Gambar 3 menunjukkan blok diagram sistem akuisisi data yang digunakan untuk pengambilan data.

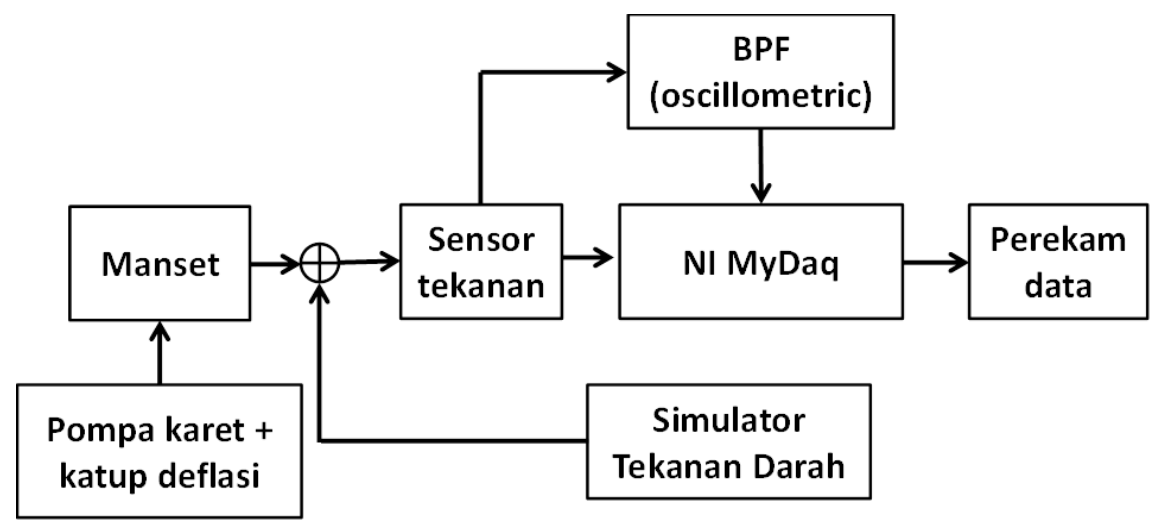

Gambar 3. Blok diagram sistem akuisisi data

Sensor tekanan yang digunakan adalah sensor tekanan tipe MPX5100GP. Sebelum digunakan untuk pengambilan data, sensor dikalibrasi terlebih dahulu menggunakan kalibrator tekanan statis tipe PPC4E dari Fluke Calibration yang juga tersedia di BPFK Jakarta. Gambar 4 menunjukkan hasil kalibrasi dalam grafik tegangan output rata-rata sensor MPX5100GP terhadap tekanan yang cukup linier untuk rentang 0-300 mmHg.

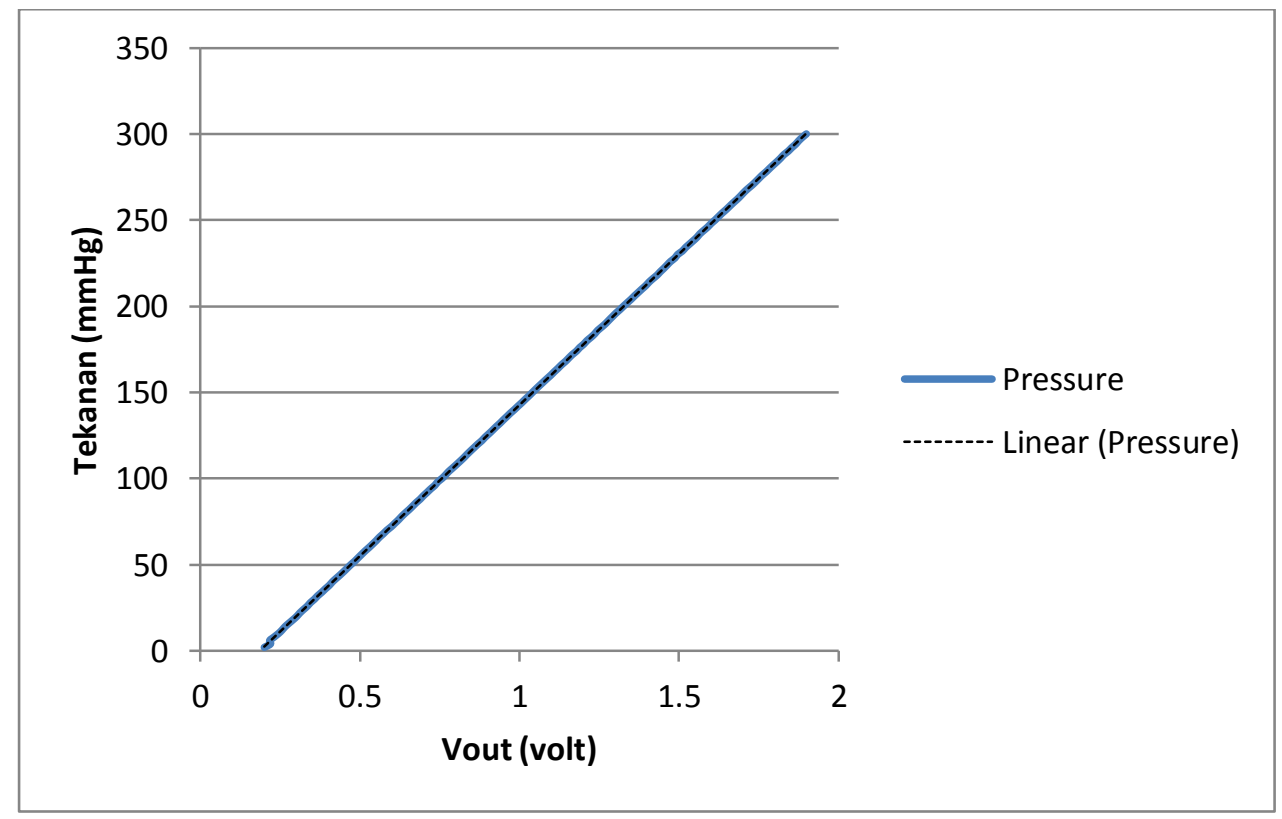

Gambar 4. Kalibrasi MPX5100GP 
Dari hasil rata-rata kalibrasi tersebut diambil persamaan garisnya menggunakan metode pencocokan kurva dan diperoleh Persamaan (1) untuk memperoleh nilai tekanan terukur.

$$
\text { Pressure }=175.350651293417 \text { Vo }-32.6445617489439
$$

BPF digunakan untuk memperoleh data osilasi tekanan pada manset yang dihasilkan oleh simulator. Karena osilasi tekanan tersebut merepresentasikan detak jantung, maka bandwidth filter disesuaikan dengan detak jantung manusia. Bandwidth BPF diset pada 0.5-5 $\mathrm{Hz}$ disesuaikan dengan detak jantung 12-120 BPM. Rangkaian BPF yang digunakan diperlihatkan pada Gambar 5. Gambar 6 menunjukkan hasil simulasi Bode plot dari rangkaian BPF menggunakan software Multisim 11.0. Pengujian langsung tidak dapat dilakukan karena frekuensi awal BPF terlalu rendah dan function generator yang tersedia tidak dapat mengeluarkan sinyal dengan frekuensi lebih kecil dari $1 \mathrm{~Hz}$.

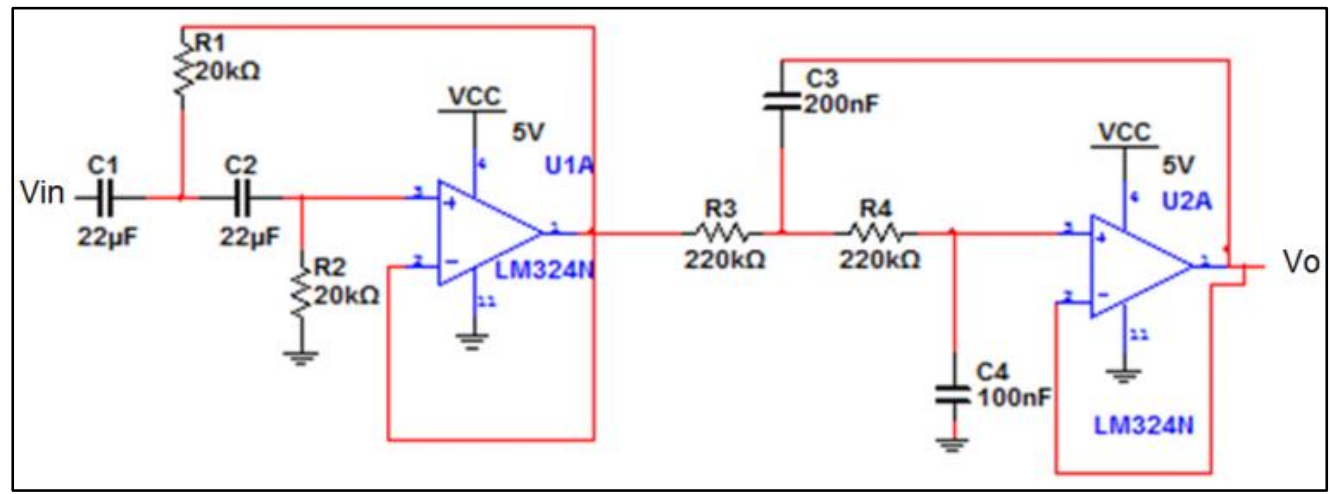

Gambar 5. Rangkaian BPF Sallen Key orde 2 (Rachmat, 2016)

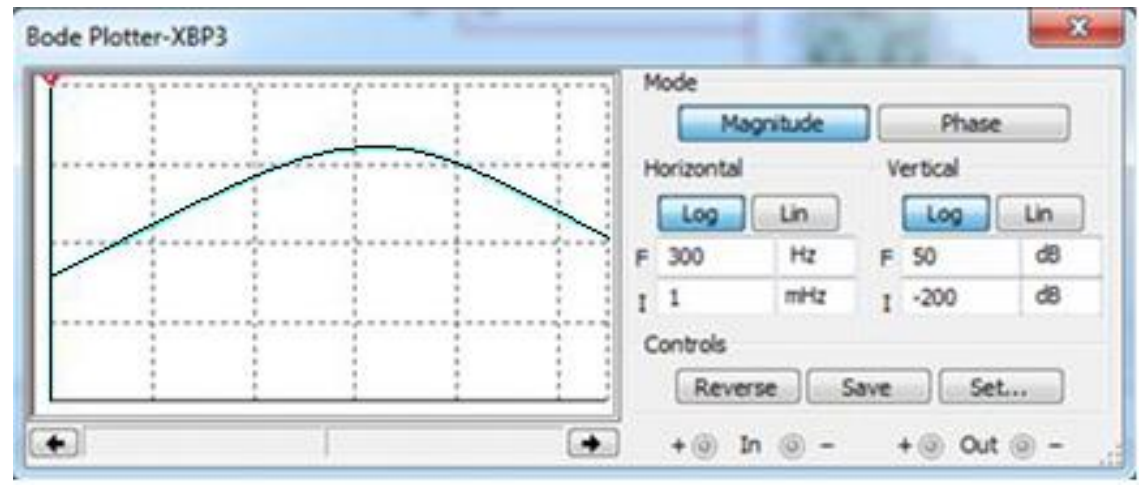

Gambar 6. Simulasi Bode plot rangkaian BPF (Rachmat, 2016)

Software perekam data dibuat menggunakan LabVIEW 2012 yang dijalankan di komputer dengan sistem operasi Windows 7. Gambar 7 menunjukkan user interface dari software yang dikembangkan, sedangkan program yang disusun menggunakan graphical programming language di LabVIEW ditunjukkan pada Gambar 8. Sebagai antarmuka antara software perekam data dengan perangkat keras digunakan NI-MyDAQ, instrumen akuisisi data dari National Instrument yang kompatibel dengan LabVIEW. 


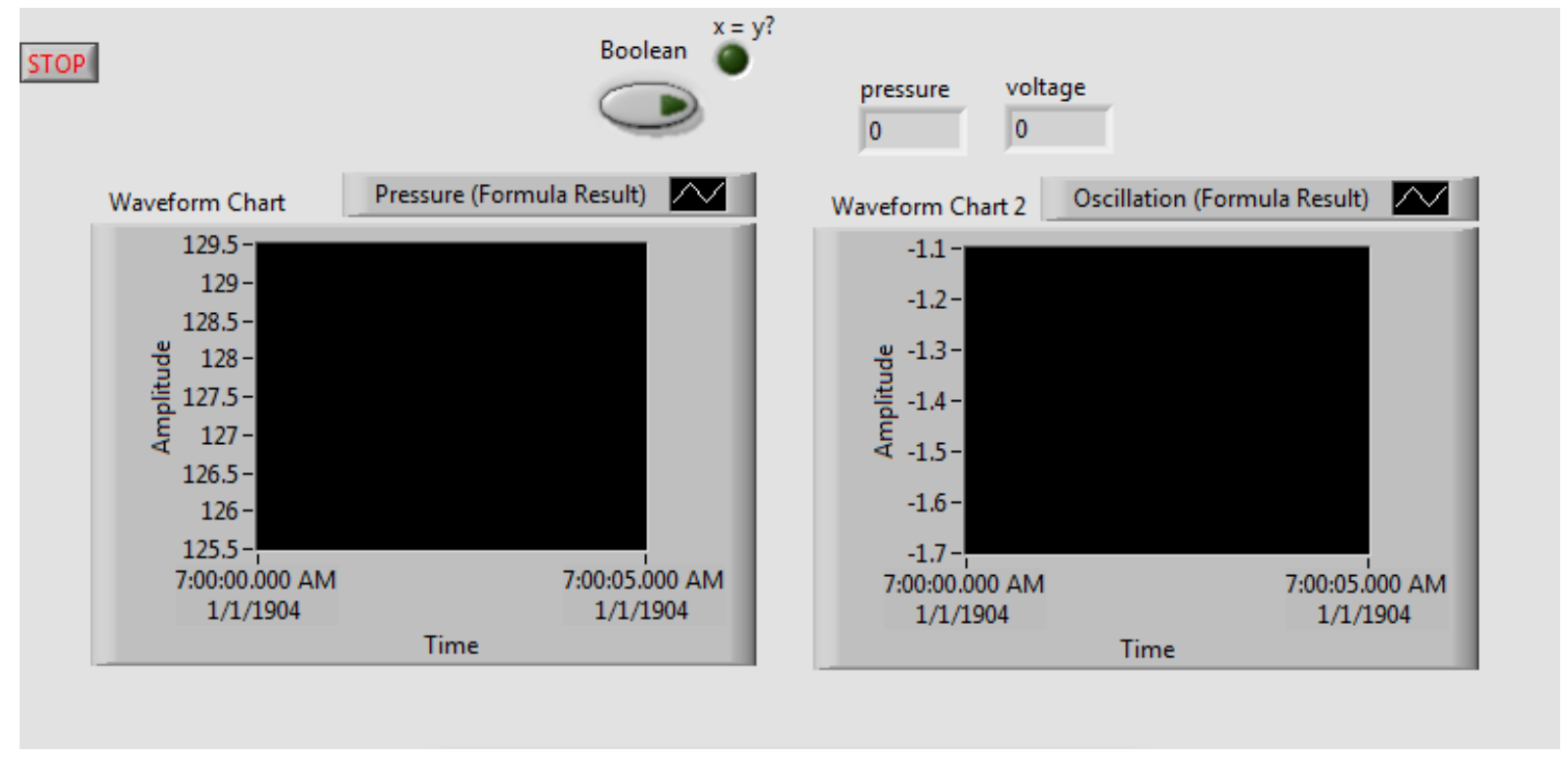

Gambar 7. User interface software perekam data

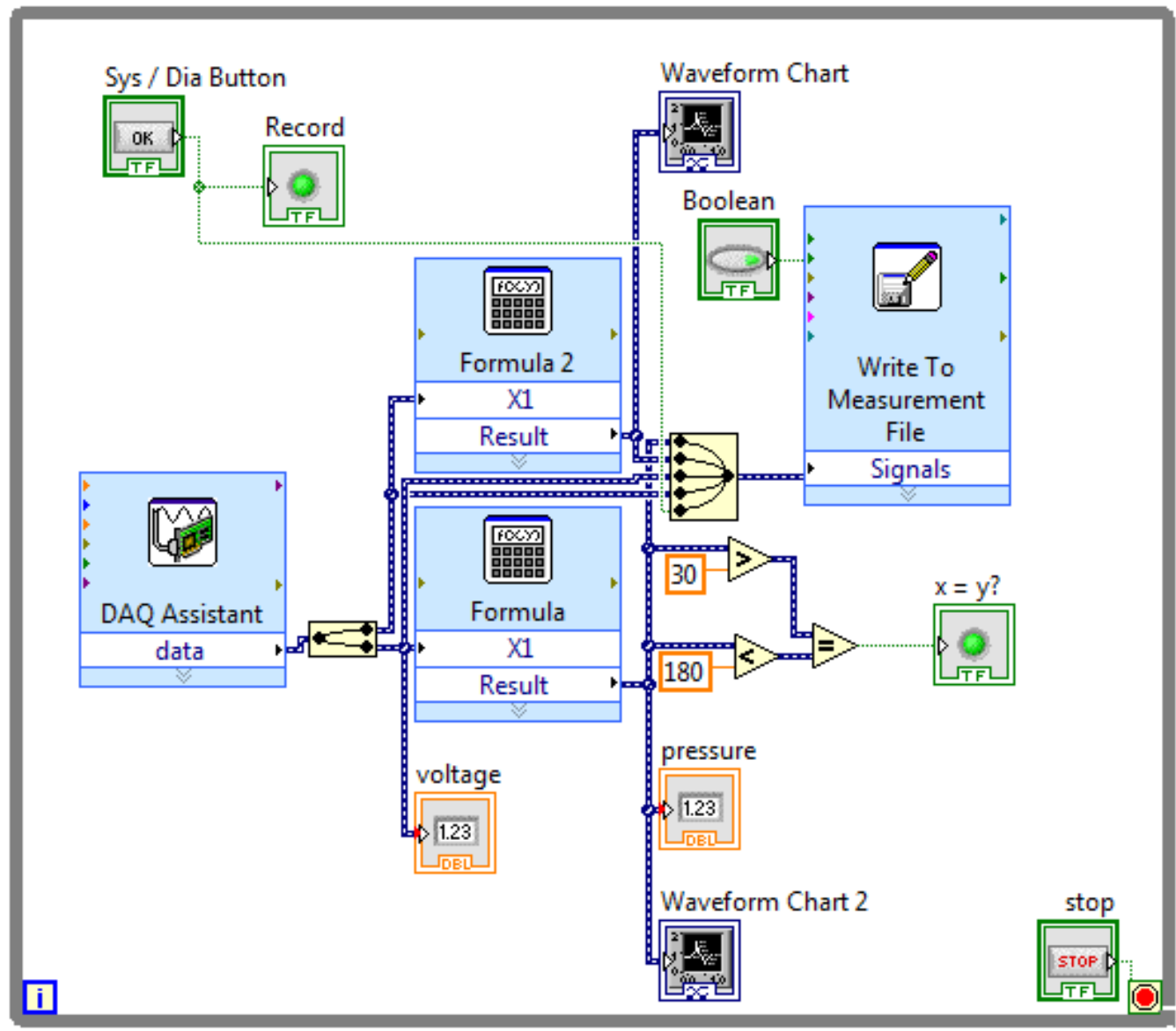

Gambar 8. Graphical code dari software perekam data 


\section{HASIL DAN PEMBAHASAN}

\subsection{Tekanan Darah 120/80 mmHg}

Salah satu grafik hasil simulasi untuk tekanan $120 / 80 \mathrm{mmHg}$ dapat dilihat pada Gambar 9, sedangkan Gambar 10 memperlihatkan perbesaran dari grafik simulasi dengan beberapa nilai waktu dan magnitudo pada beberapa titik ekstrim dan pada titik awal osilasi. Karena penguatan yang cukup besar pada magnitudo osilasi, perlu diingat bahwa satuan $\mathrm{mmHg}$ agak kurang tepat digunakan sebagai satuan magnitudo osilasi. Tetapi untuk menyederhanakan analisis data, maka satuan magnitude osilasi akan dianggap sama dengan tekanan manset, yaitu $\mathrm{mmHg}$.

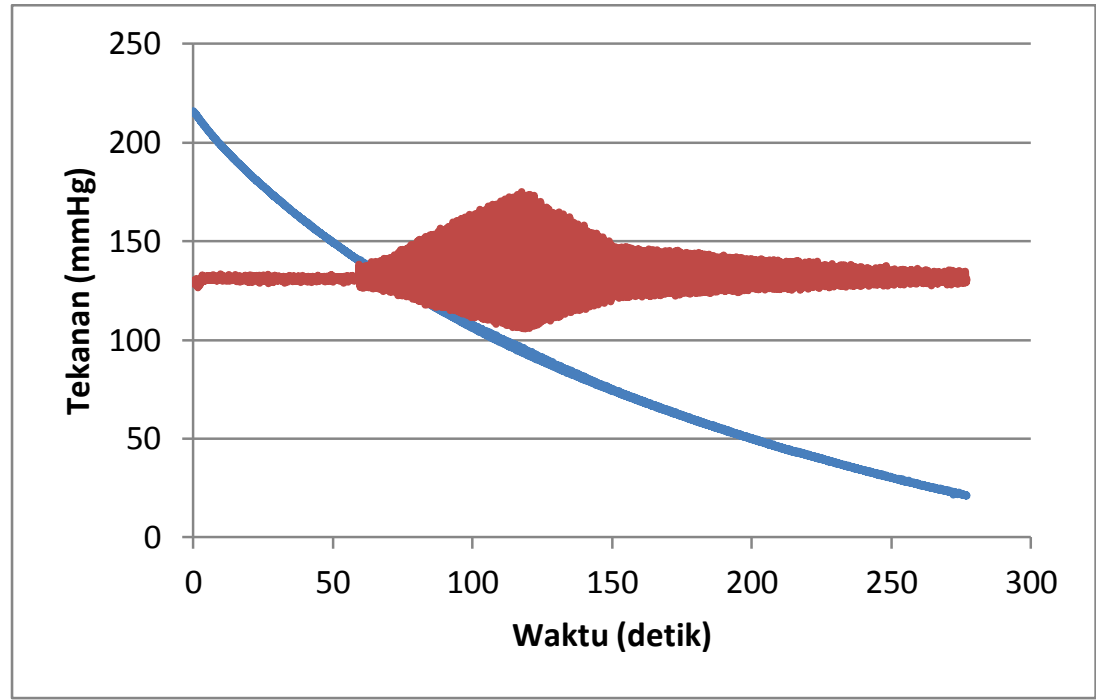

Gambar 9. Simulasi tekanan darah $120 / 80 \mathrm{mmHg}$

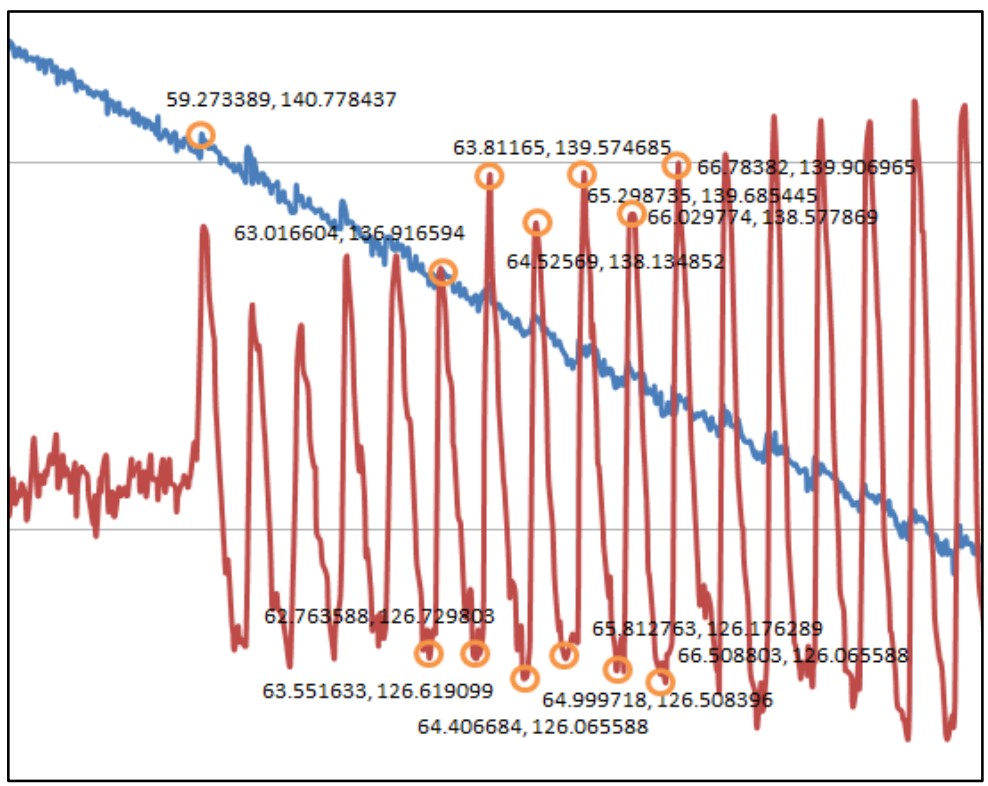

Gambar 10. Perbesaran cuplikan simulasi tekanan darah $120 / 80 \mathrm{mmHg}$

Tabel 1 memperlihatkan analisis frekuensi osilasi dari simulasi 120/80 mmHg dengan detak jantung 80 BPM yang ditunjukkan oleh titik ekstrim pada grafik di Gambar 10. Waktu ratarata per satu siklus adalah sekitar 750 milidetik. Tabel 2 memperlihatkan analisis titik mulai osilasi dan mean arterial pressure (MAP) dari tiga kali perekaman data. 
Bentuk osilasi mirip dengan bentuk osilometrik dari manusia. Osilasi naik perlahan secara linier dari titik mulai sampai titik puncak (saat MAP), lalu turun perlahan secara linier sampai tekanan sekitar $75 \mathrm{mmHg}$. Setelah itu masih terdapat osilasi dengan tingkat penurunan yang berbeda.

Tabel 1. Analisis frekuensi osilasi $120 / 80 \mathrm{mmHg}$

\begin{tabular}{|c|c|c|c|c|c|}
\hline No & $\begin{array}{c}\text { Lembah } \\
\text { (detik) }\end{array}$ & $\begin{array}{c}\text { Puncak } \\
\text { (detik) }\end{array}$ & $\begin{array}{c}\text { Waktu naik } \\
\text { (detik) }\end{array}$ & $\begin{array}{c}\text { Waktu turun } \\
\text { (detik) }\end{array}$ & $\begin{array}{c}\text { Waktu 1 siklus } \\
\text { (detik) }\end{array}$ \\
\hline 1 & 62.764 & 63.017 & 0.253 & - & - \\
\hline 2 & 63.552 & 63.817 & 0.265 & 0.535 & 0.788 \\
\hline 3 & 64.407 & 64.526 & 0.119 & 0.59 & 0.855 \\
\hline 4 & 64.999 & 65.299 & 0.3 & 0.473 & 0.592 \\
\hline 5 & 65.813 & 66.003 & 0.19 & 0.514 & 0.814 \\
\hline 6 & 66.509 & 66.784 & 0.275 & 0.506 & 0.696 \\
\hline & \multicolumn{2}{|c|}{ Rata-rata } & 0.234 & 0.524 & 0.749 \\
\hline
\end{tabular}

Tabel 2. Analisis titik mulai osilasi $120 / 80 \mathrm{mmHg}$

\begin{tabular}{|c|c|c|}
\hline No & $\begin{array}{c}\text { Tekanan awal } \\
\text { osilasi(mmHg) }\end{array}$ & $\begin{array}{c}\text { MAP } \\
(\mathbf{m m H g})\end{array}$ \\
\hline 1 & 140.778 & 96.172 \\
\hline 2 & 140.257 & 96.135 \\
\hline 3 & 140.145 & 94.279 \\
\hline Rata-rata & 140.393 & 95.529 \\
\hline
\end{tabular}

\subsection{Tekanan Darah 150/100 mmHg}

Salah satu grafik hasil simulasi untuk tekanan $150 / 100 \mathrm{mmHg}$ dapat dilihat pada Gambar 11.

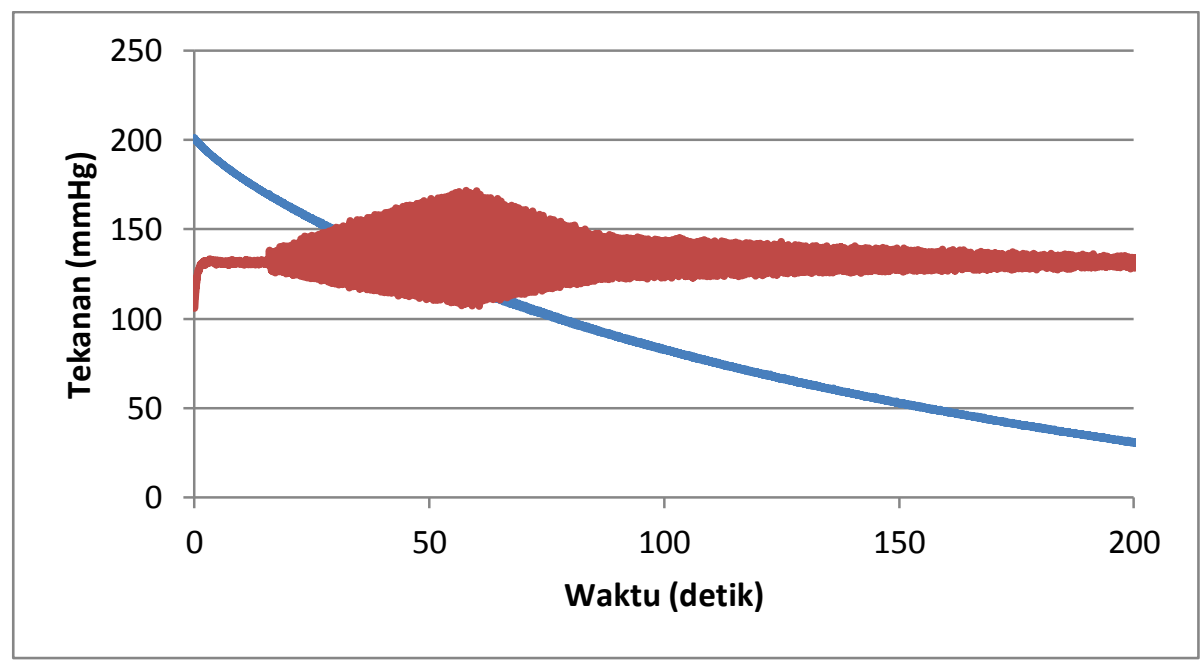

Gambar 11. Simulasi tekanan darah $150 / 100 \mathrm{mmHg}$

Tabel 3 memperlihatkan analisis frekuensi osilasi dari simulasi 150/100 mmHg dengan detak jantung 80 BPM dari beberapa titik cuplikan. Waktu rata-rata per satu siklus adalah sekitar 750 milidetik. Tabel 4 memperlihatkan analisis titik mulai osilasi dan (MAP) dari tiga kali perekaman data. 
Bentuk osilasi mirip dengan bentuk osilometrik dari manusia. Osilasi naik perlahan secara linier dari titik mulai sampai titik puncak (saat MAP), lalu turun perlahan secara linier sampai tekanan sekitar $95 \mathrm{mmHg}$. Setelah itu masih terdapat osilasi dengan tingkat penurunan yang berbeda.

Tabel 3. Analisis frekuensi osilasi $150 / 100 \mathrm{mmHg}$

\begin{tabular}{|c|c|c|c|c|c|}
\hline No & $\begin{array}{c}\text { Lembah } \\
\text { (detik) }\end{array}$ & $\begin{array}{c}\text { Puncak } \\
\text { (detik) }\end{array}$ & $\begin{array}{c}\text { Waktu naik } \\
\text { (detik) }\end{array}$ & $\begin{array}{c}\text { Waktu turun } \\
\text { (detik) }\end{array}$ & $\begin{array}{c}\text { Waktu 1 siklus } \\
\text { (detik) }\end{array}$ \\
\hline 1 & 18.228 & 18.507 & 0.279 & - & - \\
\hline 2 & 19.003 & 19.202 & 0.199 & 0.496 & 0.775 \\
\hline 3 & 19.744 & 20.023 & 0.279 & 0.542 & 0.741 \\
\hline 4 & 20.428 & 20.702 & 0.274 & 0.405 & 0.684 \\
\hline 5 & 21.221 & 21.520 & 0.299 & 0.519 & 0.793 \\
\hline 6 & 21.894 & 22.230 & 0.336 & 0.374 & 0.673 \\
\hline & \multicolumn{2}{|c|}{ Rata-rata } & 0.278 & 0.467 & 0.733 \\
\hline
\end{tabular}

Tabel 4. Analisis titik mulai osilasi $150 / 100 \mathrm{mmHg}$

\begin{tabular}{|c|c|c|}
\hline No & $\begin{array}{c}\text { Tekanan awal } \\
\text { osilasi (mmHg) }\end{array}$ & $\begin{array}{c}\text { MAP } \\
\text { (mmHg) }\end{array}$ \\
\hline 1 & 170.045 & 119.623 \\
\hline 2 & 170.045 & 119.102 \\
\hline 3 & 169.297 & 119.809 \\
\hline Rata-rata & 169.796 & 119.511 \\
\hline
\end{tabular}

\subsection{Tekanan Darah 200/150 mmHg}

Salah satu grafik hasil simulasi untuk tekanan $200 / 150$ mmHg dapat dilihat pada Gambar 12 .

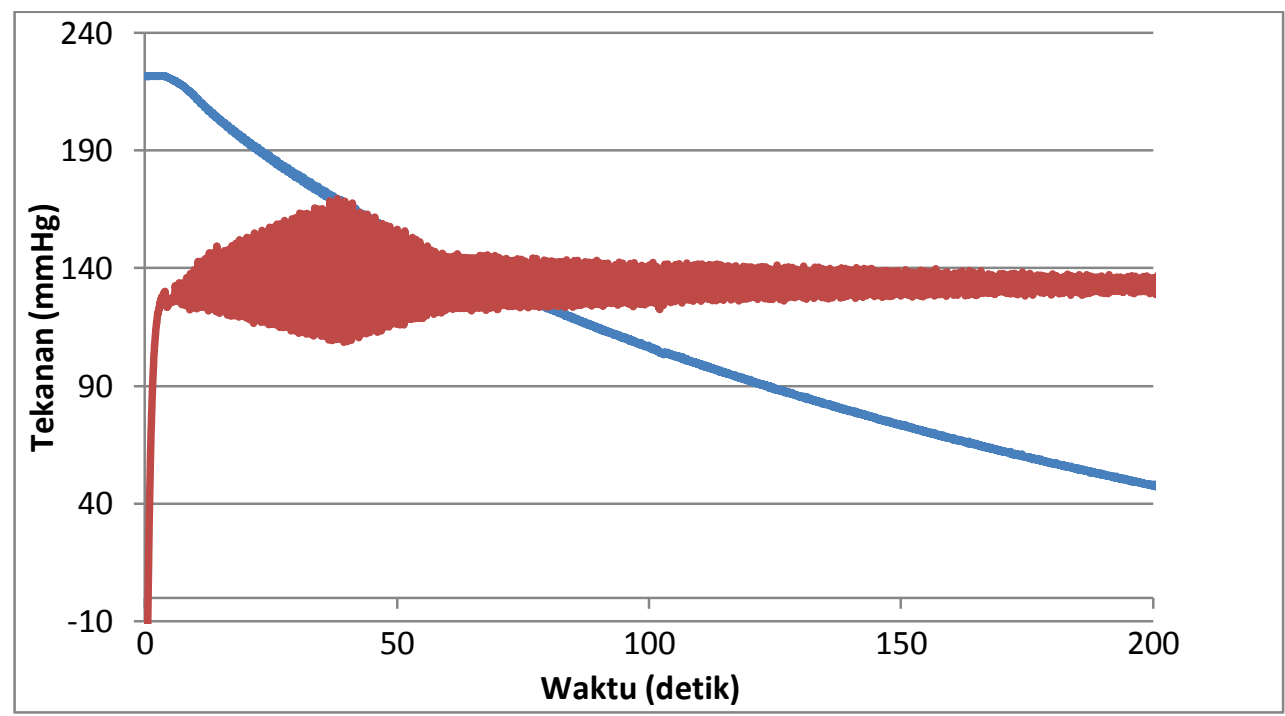

Gambar 12. Simulasi tekanan darah $200 / 150 \mathrm{mmHg}$

Tabel 5 memperlihatkan analisis frekuensi osilasi dari simulasi 200/150 mmHg dengan detak jantung 80 BPM dari beberapa titik cuplikan. Waktu rata-rata per satu siklus adalah sekitar 750 milidetik. Tabel 6 memperlihatkan analisis titik mulai osilasi dan (MAP) dari tiga kali 
perekaman data. Tetapi pada dua data perekaman data, titik mulai osilasi tidak dapat dianalisis karena osilasi sudah dimulai dari data awal.

Mirip seperti osilasi pada simulasi tekanan darah sebelumnya, osilasi naik perlahan secara linier dari titik mulai sampai titik puncak (saat MAP), lalu turun perlahan secara linier sampai tekanan sekitar $145 \mathrm{mmHg}$. Setelah itu masih terdapat osilasi dengan tingkat penurunan yang berbeda.

Tabel 5. Analisis frekuensi osilasi $200 / 150 \mathrm{mmHg}$

\begin{tabular}{|c|c|c|c|c|c|}
\hline No & $\begin{array}{l}\text { Lembah } \\
\text { (detik) }\end{array}$ & $\begin{array}{l}\text { Puncak } \\
\text { (detik) }\end{array}$ & $\begin{array}{l}\text { Waktu naik } \\
\text { (detik) }\end{array}$ & $\begin{array}{l}\text { Waktu turun } \\
\text { (detik) }\end{array}$ & $\begin{array}{c}\text { Waktu } 1 \text { siklus } \\
\text { (detik) }\end{array}$ \\
\hline 1 & 13.921 & 14.215 & 0.294 & - & - \\
\hline 2 & 14.651 & 14.948 & 0.297 & 0.436 & 0.73 \\
\hline 3 & 15.431 & 15.705 & 0.274 & 0.483 & 0.78 \\
\hline 4 & 16.215 & 16.497 & 0.282 & 0.51 & 0.784 \\
\hline 5 & 16.998 & 17.197 & 0.199 & 0.501 & 0.783 \\
\hline 6 & 17.642 & 17.938 & 0.296 & 0.445 & 0.644 \\
\hline & \multicolumn{2}{|c|}{ Rata-rata } & 0.274 & 0.475 & 0.744 \\
\hline
\end{tabular}

Tabel 6. Analisis titik mulai osilasi $200 / 150 \mathrm{mmHg}$

\begin{tabular}{|c|c|c|}
\hline No & $\begin{array}{c}\text { Tekanan awal } \\
\text { osilasi (mmHg) }\end{array}$ & $\begin{array}{c}\text { MAP } \\
\text { (mmHg) }\end{array}$ \\
\hline 1 & - & 169.941 \\
\hline 2 & - & 168.251 \\
\hline 3 & 220.039 & 169.671 \\
\hline Rata-rata & 220.039 & 169.288 \\
\hline
\end{tabular}

\subsection{Tekanan Darah 60/30 mmHg}

Salah satu grafik hasil simulasi untuk tekanan $60 / 30 \mathrm{mmHg}$ dapat dilihat pada Gambar 13 .

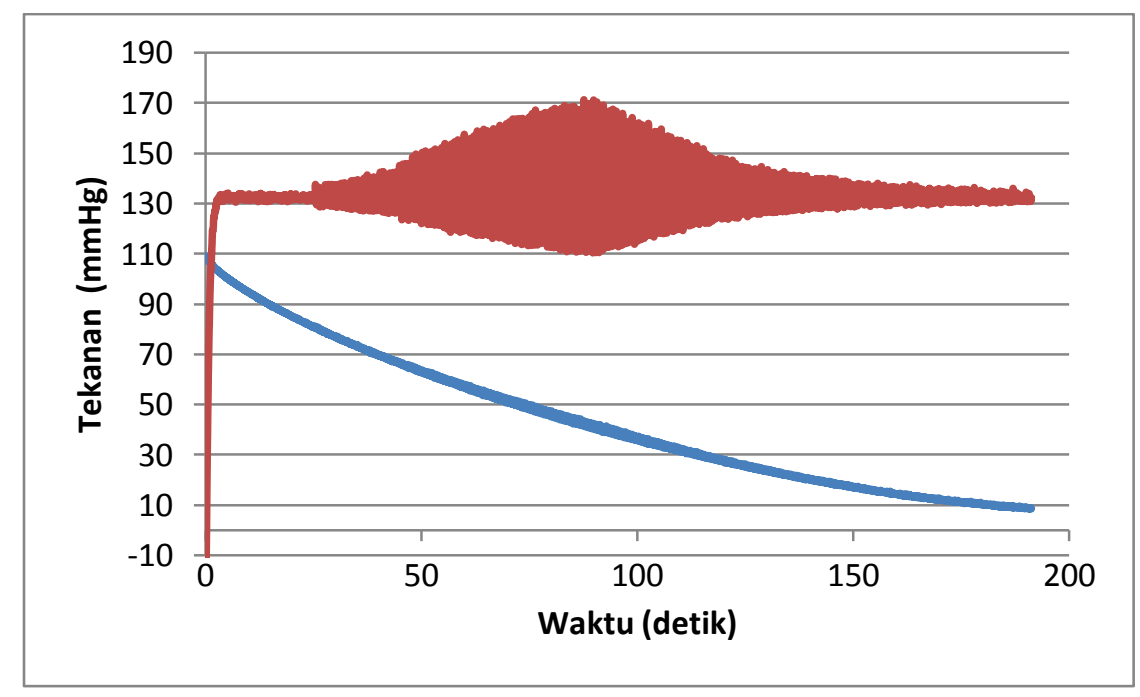

Gambar 13. Simulasi tekanan darah $60 / 30 \mathrm{mmHg}$ 
Tabel 7 memperlihatkan analisis frekuensi osilasi dari simulasi $60 / 30 \mathrm{mmHg}$ dengan detak jantung 80 BPM dari beberapa titik cuplikan. Waktu rata-rata per satu siklus adalah sekitar 750 milidetik. Tabel 8 memperlihatkan analisis titik mulai osilasi dan (MAP) dari tiga kali perekaman data.

Mirip seperti osilasi pada simulasi tekanan darah sebelumnya, osilasi naik perlahan secara linier dari titik mulai sampai titik puncak (saat MAP), lalu turun perlahan secara linier sampai tekanan sekitar $25 \mathrm{mmHg}$. Setelah itu masih terdapat osilasi dengan tingkat penurunan yang berbeda.

Tabel 7. Analisis frekuensi osilasi $60 / 30 \mathrm{mmHg}$

\begin{tabular}{|c|c|c|c|c|c|}
\hline No & $\begin{array}{c}\text { Lembah } \\
\text { (detik) }\end{array}$ & $\begin{array}{c}\text { Puncak } \\
\text { (detik) }\end{array}$ & $\begin{array}{c}\text { Waktu naik } \\
\text { (detik) }\end{array}$ & $\begin{array}{c}\text { Waktu turun } \\
\text { (detik) }\end{array}$ & $\begin{array}{c}\text { Waktu 1 siklus } \\
\text { (detik) }\end{array}$ \\
\hline 1 & 30.415 & 30.774 & 0.359 & - & - \\
\hline 2 & 31.304 & 31.479 & 0.175 & 0.53 & 0.889 \\
\hline 3 & 31.985 & 32.238 & 0.253 & 0.506 & 0.681 \\
\hline 4 & 32.722 & 33.014 & 0.292 & 0.484 & 0.737 \\
\hline 5 & 33.643 & 33.739 & 0.096 & 0.629 & 0.921 \\
\hline 6 & 34.177 & 34.489 & 0.312 & 0.438 & 0.534 \\
\hline \multicolumn{3}{|c|}{ Rata-rata } & 0.248 & 0.517 & 0.752 \\
\hline
\end{tabular}

Tabel 8. Analisis titik mulai osilasi $60 / 30 \mathrm{mmHg}$

\begin{tabular}{|c|c|c|}
\hline No & $\begin{array}{c}\text { Tekanan awal } \\
\text { osilasi }(\mathbf{m m H g})\end{array}$ & $\begin{array}{c}\text { MAP } \\
(\mathbf{m m H g})\end{array}$ \\
\hline 1 & 80.631 & 43.203 \\
\hline 2 & 79.037 & 42.797 \\
\hline 3 & 80.742 & 42.059 \\
\hline Rata-rata & 80.137 & 42.686 \\
\hline
\end{tabular}

\subsection{Tekanan Darah 80/50 mmHg}

Salah satu grafik hasil simulasi untuk tekanan $80 / 50 \mathrm{mmHg}$ dapat dilihat pada Gambar 14 .

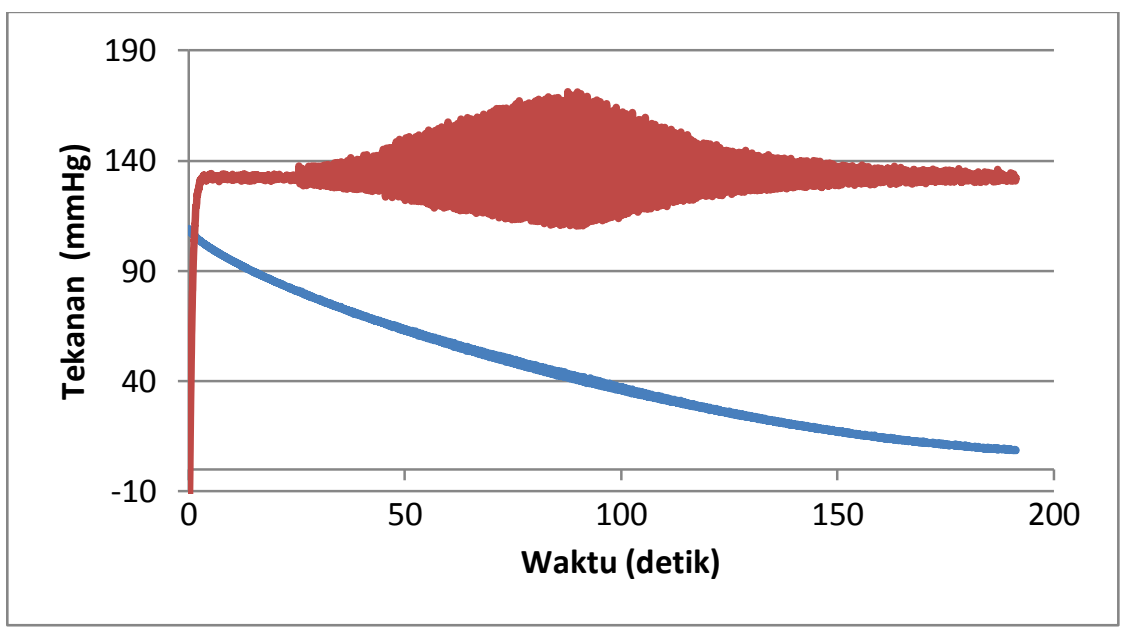

Gambar 14. Simulasi tekanan darah $80 / 50 \mathrm{mmHg}$ 
Tabel 9 memperlihatkan analisis frekuensi osilasi dari simulasi $80 / 50 \mathrm{mmHg}$ dengan detak jantung 80 BPM dari beberapa titik cuplikan. Waktu rata-rata per satu siklus adalah sekitar 750 milidetik. Tabel 10 memperlihatkan analisis titik mulai osilasi dan (MAP) dari tiga kali perekaman data.

Mirip seperti osilasi pada simulasi tekanan darah sebelumnya, osilasi naik perlahan secara linier dari titik mulai sampai titik puncak (saat MAP), lalu turun perlahan secara linier sampai tekanan sekitar $45 \mathrm{mmHg}$. Setelah itu masih terdapat osilasi dengan tingkat penurunan yang berbeda.

Tabel 9. Analisis frekuensi osilasi $80 / 50 \mathrm{mmHg}$

\begin{tabular}{|c|c|c|c|c|c|}
\hline No & $\begin{array}{c}\text { Lembah } \\
\text { (detik) }\end{array}$ & $\begin{array}{c}\text { Puncak } \\
\text { (detik) }\end{array}$ & $\begin{array}{c}\text { Waktu naik } \\
\text { (detik) }\end{array}$ & $\begin{array}{c}\text { Waktu turun } \\
\text { (detik) }\end{array}$ & $\begin{array}{c}\text { Waktu 1 siklus } \\
\text { (detik) }\end{array}$ \\
\hline 1 & 78.750 & 79.045 & 0.295 & - & - \\
\hline 2 & 79.531 & 79.826 & 0.295 & 0.486 & 0.781 \\
\hline 3 & 80.236 & 80.549 & 0.313 & 0.41 & 0.705 \\
\hline 4 & 80.999 & 81.291 & 0.292 & 0.45 & 0.763 \\
\hline 5 & 81.777 & 82.068 & 0.291 & 0.486 & 0.778 \\
\hline 6 & 82.547 & 82.782 & 0.235 & 0.479 & 0.77 \\
\hline \multicolumn{3}{|c|}{ Rata-rata } & 0.287 & 0.462 & 0.759 \\
\hline
\end{tabular}

Tabel 10. Analisis titik mulai osilasi $80 / 50 \mathrm{mmHg}$

\begin{tabular}{|c|c|c|}
\hline No & $\begin{array}{c}\text { Tekanan awal } \\
\text { osilasi }(\mathbf{m m H g})\end{array}$ & $\begin{array}{c}\text { MAP } \\
(\mathbf{m m H g})\end{array}$ \\
\hline 1 & 100.145 & 63.081 \\
\hline 2 & 100.591 & 63.747 \\
\hline 3 & 100.813 & 62.896 \\
\hline Rata-rata & 100.516 & 63.241 \\
\hline
\end{tabular}

\subsection{Tekanan Darah 100/65 mmHg}

Salah satu grafik hasil simulasi untuk tekanan $100 / 65 \mathrm{mmHg}$ dapat dilihat pada Gambar 15.

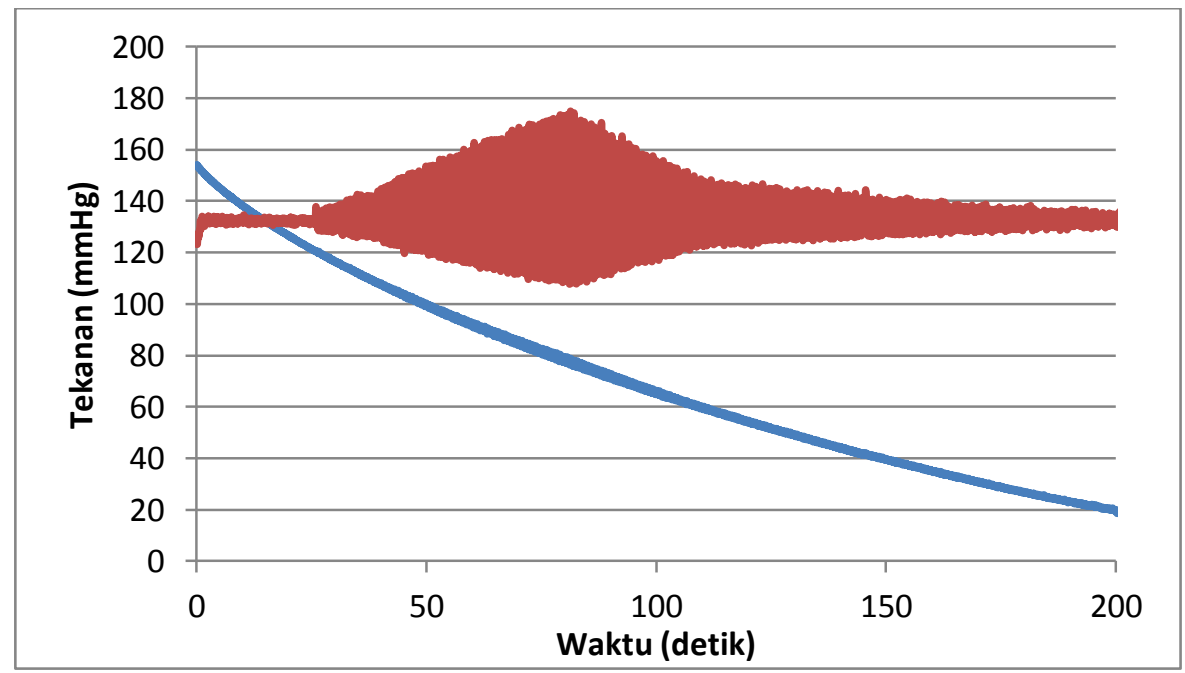

Gambar 15. Simulasi tekanan darah $100 / 65 \mathrm{mmHg}$ 
Tabel 11 memperlihatkan analisis frekuensi osilasi dari simulasi 100/65 mmHg dengan detak jantung 80 BPM dari beberapa titik cuplikan. Waktu rata-rata per satu siklus adalah sekitar 750 milidetik. Tabel 12 memperlihatkan analisis titik mulai osilasi dan (MAP) dari tiga kali perekaman data.

Mirip seperti osilasi pada simulasi tekanan darah sebelumnya, osilasi naik perlahan secara linier dari titik mulai sampai titik puncak (saat MAP), lalu turun perlahan secara linier sampai tekanan sekitar $60 \mathrm{mmHg}$. Setelah itu masih terdapat osilasi dengan tingkat penurunan yang berbeda.

Tabel 11. Analisis frekuensi osilasi $100 / 65 \mathrm{mmHg}$

\begin{tabular}{|c|c|c|c|c|c|}
\hline No & $\begin{array}{c}\text { Lembah } \\
\text { (detik) }\end{array}$ & $\begin{array}{c}\text { Puncak } \\
\text { (detik) }\end{array}$ & $\begin{array}{c}\text { Waktu naik } \\
\text { (detik) }\end{array}$ & $\begin{array}{c}\text { Waktu turun } \\
\text { (detik) }\end{array}$ & $\begin{array}{c}\text { Waktu 1 siklus } \\
\text { (detik) }\end{array}$ \\
\hline 1 & 38.320 & 38.556 & 0.236 & - & - \\
\hline 2 & 39.003 & 39.314 & 0.311 & 0.447 & 0.683 \\
\hline 3 & 39.782 & 40.074 & 0.292 & 0.468 & 0.779 \\
\hline 4 & 40.553 & 40.844 & 0.291 & 0.479 & 0.771 \\
\hline 5 & 41.232 & 41.545 & 0.313 & 0.388 & 0.679 \\
\hline 6 & 42.011 & 42.299 & 0.288 & 0.466 & 0.779 \\
\hline \multicolumn{2}{|c|}{ Rata-rata } & 0.289 & 0.450 & 0.738 \\
\hline
\end{tabular}

Tabel 12. Analisis titik mulai osilasi $100 / 65 \mathrm{mmHg}$

\begin{tabular}{|c|c|c|}
\hline No & $\begin{array}{c}\text { Tekanan awal } \\
\text { osilasi }(\mathbf{m m H g})\end{array}$ & $\begin{array}{c}\text { MAP } \\
(\mathbf{m m H g})\end{array}$ \\
\hline 1 & 120.628 & 78.519 \\
\hline 2 & 120.702 & 79.927 \\
\hline 3 & 120.442 & 79.111 \\
\hline Rata-rata & 120.591 & 79.186 \\
\hline
\end{tabular}

\section{KESIMPULAN}

Dari hasil perekaman data dengan metode deflasi untuk beberapa variasi tekanan darah dengan detak jantung 80 BPM, maka dapat disimpulkan beberapa karakteristik osilometrik dari simulator referensi pada mode standard BP.

Dengan detak jantung 80 BPM, osilasi muncul sekitar 750 milidetik sekali dengan durasi naik lebih singkat daripada durasi turun per satu siklus osilasi, yaitu sekitar 250 milidetik untuk naik dan 500 milidetik untuk turun. Bentuk osilasi yang dihasilkan oleh simulator referensi cukup mirip dengan bentuk osilometrik dari pasien. Osilasi dimulai pada tekanan $20 \mathrm{mmHg}$ di atas nilai tekanan sistol untuk seluruh variasi tekanan darah. Magnitude osilasi perlahan naik secara linier dari titik mulai osilasi sampai ke titik MAP, lalu perlahan turun secara linier sampai pada satu titik tertentu, yaitu pada sekitar tekanan $5 \mathrm{mmHg}$ di bawah nilai tekanan diastol.

Nilai MAP pada tiap variasi tekanan darah adalah sebagai berikut: (1) $120 / 80 \mathrm{mmHg}$ adalah $96 \mathrm{mmHg}$; (2) 150/100 mmHg adalah $93 \mathrm{mmHg}$; (3) 200/150 mmHg adalah $120 \mathrm{mmHg}$; (3) $255 / 195 \mathrm{mmHg}$ adalah $169 \mathrm{mmHg}$; (4) $60 / 30 \mathrm{mmHg}$ adalah $43 \mathrm{mmHg}$; (5) $80 / 50 \mathrm{mmHg}$ adalah $63 \mathrm{mmHg}$; (5) 100/65 mmHg adalah $79 \mathrm{mmHg}$. 
Hasil dari studi ini telah digunakan pada pengembangan simulator tekanan darah, dengan fokus awal pada simulasi tekanan darah $120 / 80 \mathrm{mmHg}$, dengan karakteristik osilasi dimulai pada tekanan manset $140 \mathrm{mmHg}$ dan MAP ditargetkan pada $96 \mathrm{mmHg}$. Tetapi perbedaan tingkat penurunan masih belum diterapkan pada pengembangan awal tersebut. Hasil pengembangan awal tersebut menghasilkan simulasi rata-rata sistol $118 \pm 2 \mathrm{mmHg}$ dan diastol $77 \pm 1 \mathrm{mmHg}$, dengan MAP $98.9 \pm 0.6 \mathrm{mmHg}$ (Ughi, dkk, 2016). Hasil simulasi purwarupa pengembangan awal masih belum sesuai dengan target, sehingga masih perlu dikembangkan lebih lanjut.

Agar karakteristik osilometrik lebih lengkap, pengambilan data dengan metode pengukuran inflasi perlu dilakukan. Dengan begitu dapat diketahui titik mulai osilasi pada metode inflasi yang mungkin dapat dikaitkan dengan nilai tekanan diastol. Selain itu dapat dilihat konsistensi nilai MAP pada metode inflasi dibandingkan dengan metode deflasi.

\section{UCAPAN TERIMA KASIH}

Terima kasih untuk Academic Research and Community Service (ARCS), Swiss German University untuk pendanaan studi ini, dan kepada tim Laboratorium Pengujian dan Kalibrasi Instrumen Medis, Balai Pengamanan Fasilitas Kesehatan Jakarta untuk izin dan bantuannya dalam proses pengambilan data.

\section{DAFTAR RUJUKAN}

Wikimedia Commons. (2006). Korotkow deutsch.png. Dipetik Agustus 29, 2016, dari https://commons.wikimedia.org/wiki/File:Korotkow_deutsch.png

Ball-llovera, A.; Del Rey, A.; Ruso, R.; Ramos, J.; Batista, O.; Niubo, I. (2003). An Experience in Implementing the Oscillometric Algorithm for the Non-Invasive Determination of Human Blood Pressure. Proceeding of the $25^{\text {th }}$ Annual International Conference of the IEEE EMBS (pp. 3173-3175). Cancun.

Geršak, G; Žemva, A.; Drnovšek, J. (2009). A procedure for evaluation of non-invasive blood pressure simulators. Med Biol Eng Comput. 47: 1221-1228.

Fluke Biomedical. (2007). BP Pump 2 NIBP Simulator and Tester - Operators Manual. Washington.

Plante, T.B.; Urrea, B.; MacFarlane, Z.T.; Blumental, R.S.; Miller III, E.R.; Appel, L.J., Martin, S.S. (2016). Validation of the Instant Blood Pressure Smartphone App. Jama Internal Medicine (pp. E1-E2). Dipetik September 8, 2016, dari http://www.djsehealth.nl/wpcontent/uploads/2016/03/Bloeddruk.pdf

Perhimpunan Hipertensi Indonesia. (2012). Referensi Populer Untuk Masyarakat Umum Kenalilah Tekanan Darah Anda. Direktorat Penyakit Tidak Menular Kemenkes R.I. Jakarta

Rachmat, H.H.; Ughi, F. (2016). Perancangan dan Realisasi Sistem Tele-Monitoring dan Rekam Medis Kesehatan Pasien Penyandang Tuna Netra dan Usia Lanjut. Laporan Kemajuan Penelitian Hibah Bersaing. LPPM Itenas. Bandung. 
Ughi, F.; Dewanto, G.A.; Abdillah, A.; Yuliyanto, A. (2016). Low-Cost Simulator for Oscillometric Non-Invasive Blood Pressure Measurement. Proceeding of $2^{\text {nd }}$ International Conference on Science, Technology and Interdisciplinary Research 2016 (p. 91). Bandar Lampung. 